On 24 August last year Professor Henry Bedson of the Department of Medical Microbiology at Birmingham University analysed samples from Mrs Janet Parker, a university photographer, and confirmed that she had smallpox. The source of her infection was almost certainly Bedson's smallpox laboratory. Within a few weeks Professor Bedson had committed suicide and Mrs Parker had died. The affair is $s u b$ judice under the pending court case against Birmingham University under the Health and
Safety at Work Act, but despite that Clive Jenkins, leader of the Association of Scientific, Technical and Managerial Staffs last week published his copy of the Shooter report-the confidential government report of the committee of inquiry into the incident. Shooter's indictment is a strong one, and Mr Jenkins believed it in "the over-riding public interest" that he publish it. Here Robin McKie of the Times Higher Education Supplement, Mary Lindley, Judy Redfearn and Robert Walgate report.

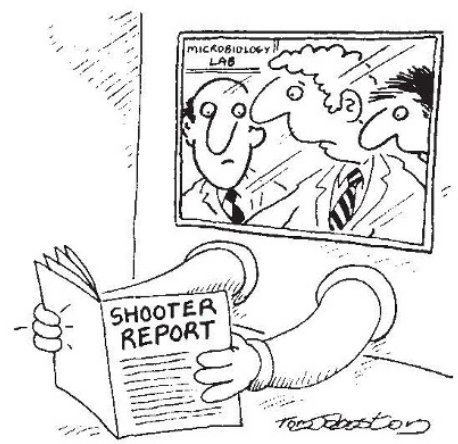

\title{
UK smallpox research could continue at Porton
}

The unofficial publication of the Shooter report by union leader Clive Jenkins last week is likely to produce swift results in Britain. The recommendation that the nation's only remaining smallpox research unit, at $\mathrm{St}$ Mary's Hospital in London, should be moved to an isolated area in the country has already been backed by the local Member of Parliament, $\mathrm{Mr}$ Arthur Latham. And the head of the unit, Professor Keith Dumbell, admitted that it would now be impossible for smallpox research to be carried out at St Mary's.

However, later in the week Dr David Simpson, recently appointed director of the special pathogens unit at the Medical Research Establishment, Porton, told Nature that he would be willing to receive Professor Dumbell's live smallpox virus at Porton. He could store it there, said Dr Simpson, but he did not want Porton to become "just rent-a-space". Any researcher using Porton in this way would be expected to use and collaborate with Porton staff in research on the material so stored.

Professor Dumbell, on the other hand, believes the scientific case for moving is arguable. "We have in our laboratory all the precautions that we have been able to think up. The chances of a virus escaping are very much smaller than those risks to which we expose ourselves everyday", Professor Dumbell added.

His laboratory was a purpose-built unit designed to cope with smallpox research and took two years to set up. The safeguards-in contrast to the inadequate measures disclosed at $\mathrm{Bir}$ mingham-include a sealed anteroom; effective laboratory air filtration; antiseptic disposable clothing; a shower room; and regular vaccinations. The move to the country would cost two years' effort that could otherwise be used for smallpox research, he stated.

If the smallpox laboratory at St. Mary's had to close it would be for political reasons, added the school's dean, Dr Harold Edwards. The move to the country would only serve to isolate the smallpox resarchers from colleagues involved in similar areas of work. And Dr Edwards warned that the controversy surrounding the Birmingham smallpox outbreak could lead to growing demands for tighter controls which would diminish the quantity of scientific research in Britain. "The trouble is that increases in controls are not followed by the necessary increases in public funds.
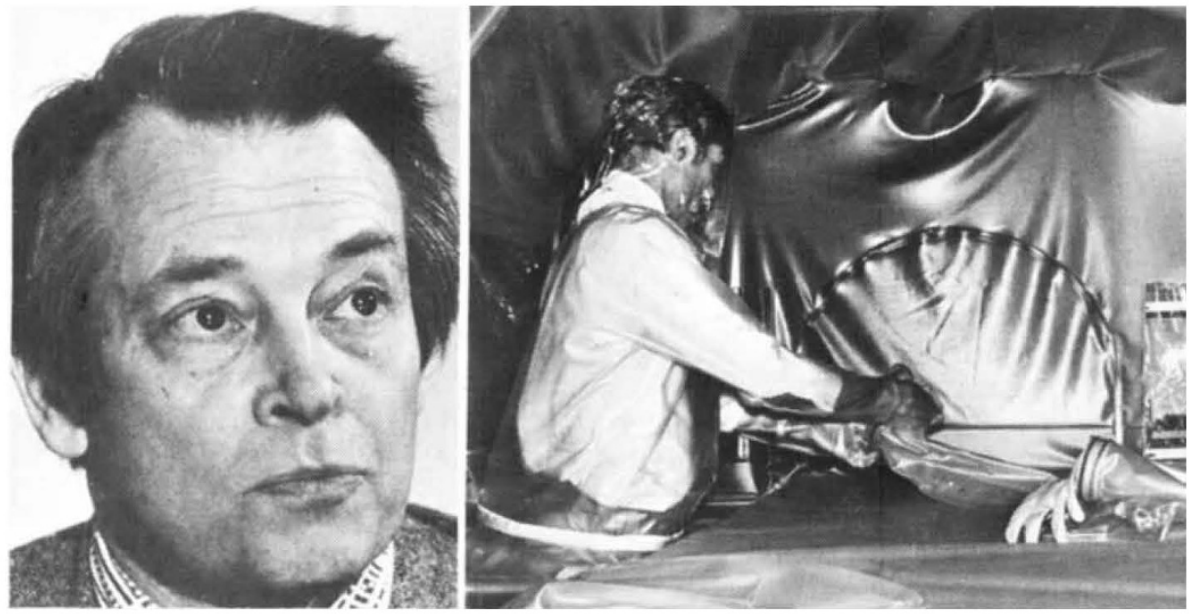

Professor Keith Dumbell (left) and the sort of facilities at Porton (right) with which he could continue smallpox research.

Something else has to be taken out of research funds to achieve new safety standards".

Professor Dumbell, who supplied Professor Bedson at Birmingham with 22 virus strains including the one which killed Mrs Parker, admitted there had been a misdemeanour involved when they did not inform the Dangerous Pathogens Advisory Group (DPAG) of the transfer. He thought both of them had assumed the other had notified the group.

Professor Bedson and Professor Dumbell were working on parallel lines of research. At Birmingham, Professor Bedson was using the protein coats of viruses as the basis of an identification process, while Professor Dumbell was attempting a similar technique using the DNA of viruses.

Asked if Professor Bedson could have carried on his work at St. Mary's instead of rushing to complete it at Birmingham, Professor Dumbell said that when the World Health Organisation indicated it was to close down all smallpox research units in Britain, apart from the one at St Mary's, he had been asked by the researchers if he would provide space for them to continue their work. "I answered that I was prepared to do this".

\section{How the virus escaped}

THE Birmingham smallpox laboratory which was the source of the infection which killed Mrs Janet Parker, is a tiny, eight-foot square room in the east wing of Birmingham University's medical school. It is surrounded by a larger room in which experiments on animal pox viruses were performed. Both rooms contain equipment used in normal microbiological research, including safety cabinets with air filters, centrifuges and autoclaves for sterilising gowns and equipment.

The Shooter committee firstly found there was no evidence that Mrs Parker had ever been in the pox virus labora- 